Cahiers $d u$ MONDE RUSSE

\section{Cahiers du monde russe}

Russie - Empire russe - Union soviétique et États indépendants

55/3-4 | 2014

Varia

\title{
Eric Lohr, Russian Citizenship, From Empire to Soviet Union
}

Mikhail Dolbilov

\section{OpenEdition}

\section{Journals}

Electronic version

URL: http://journals.openedition.org/monderusse/8058

DOI: $10.4000 /$ monderusse. 8058

ISSN: $1777-5388$

\section{Publisher}

Éditions de l'EHESS

\section{Printed version}

Date of publication: 1 July 2014

Number of pages: 392-396

ISBN: 978-2-7132-2441-6

ISSN: $1252-6576$

Electronic reference

Mikhail Dolbilov, «Eric Lohr, Russian Citizenship, From Empire to Soviet Union », Cahiers du monde russe [Online], 55/3-4 | 2014, Online since 13 April 2015, Connection on 24 September 2020. URL : http://journals.openedition.org/monderusse/8058 ; DOI : https://doi.org/10.4000/monderusse.8058

This text was automatically generated on 24 September 2020

(c) École des hautes études en sciences sociales 


\title{
Eric Lohr, Russian Citizenship, From Empire to Soviet Union
}

\author{
Mikhail Dolbilov
}

\section{REFERENCES}

Eric LOHR, Russian Citizenship, From Empire to Soviet Union, Cambridge, MA Londres : Harvard University Press, 2012, 278 p.

1 This well-written and clearly argued book tells a complex story of late imperial and early Soviet citizenship through the prism of four "exit-entry" civil transitions immigration, emigration, naturalization, and denaturalization. Eric Lohr approaches the issues of citizenry and citizenship from the perspective of the individual's membership in a polity and the concomitant regulations and procedures, rather than from the standpoint of the individual's rights and autonomy vis-à-vis the state and the authorities. In this light, the $19^{\text {th }}$ - and $20^{\text {th }}$-century history of Russian citizenship emerges as far more comparable to, and entangled with, its Western counterparts than has been portrayed by historians and legal thinkers focused on the state-society nexus or on the prevalence of illiberal and anti-civic ideologies in Russia. In the author's own words, what the book means by "citizenship" is not so much "a set of legal precedents" as, "in a more anthropological sense, a national "citizenship tradition"” (p. 10), somewhat elusive but sustainable; hence, he proposes, there are unexpected commonalities and parallels between distant historical eras, the ruptures notwithstanding.

2 There are two central themes in Lohr's argument and narrative. The first one is late imperial Russia's uneven yet fairly steadfast evolution from the particularistic paradigm of subjecthood, based on the monarchy's "separate deals" with diverse social groups and ethnic and religious minorities, toward a more universalized and uniform system of citizenship. The second theme is the Russian state's "attract and hold" handling of issues of entry into and exit from subjecthood/citizenship - a function also 
referred to in the monograph as the "filtering state" (p. 8) - which suggested the use of immigration and emigration for optimizing the social, national, or religious makeup of the population along the lines of political-social reliability or economic profit. A relatively stable balance between the "attract" and "hold" continued, the argument goes, from the late 1850 s up to the outbreak of WWI.

The processes of immigration and naturalization are discussed, first and foremost, in relation to the liberalizing changes in foreigners' rights under Alexander II and to the controversies and clashes over border control policies. Thus, a series of laws and rules were implemented in the late 1850 s and early 1860 s to lift the vexatious bans on the entry of foreigners and to revoke further restrictions on their economic activities in Russia, simultaneously granting them a number of new tangible rights and exemptions, mostly regarding commerce, trade, and ownership (landed property included). The unequivocal goal of what Lohr boldly calls one of "the most overlooked of the great reforms" was to "facilitate an immigration of merchants, entrepreneurs, technicians, and managers from abroad" (p. 48, 52). In a noticeable break from the previous policy, naturalization was no longer a prerequisite for enjoying these entrepreneurial opportunities - for example, now foreigners seeking to enter Russian merchant guilds did not have to naturalize. In fact, Lohr argues, this "gave foreigners full equality to subjects under civil law" (p.55). I would add that it gave foreigners full equality to subjects within a certain social group or order, as the soslovie differences still mattered greatly.

4 In the same vein, Alexander II's government streamlined the procedure of naturalization itself, particularly eliminating the intermediary denizen-like status of a naturalized foreigner as distinct from natural-born subjects (its counterpart in the contemporaneous nationality and assimilatory policies, one could argue, was the status of a "baptized inorodets") and encouraging the naturalization of foreigners' children and foreigners born on Russian soil. At a conceptual level, the reformed procedure signaled a shift toward defining subjecthood more through universal membership in the country rather than acceptance into a particular soslovie body. Interestingly, one of the immediate consequences of this liberalization was not a heightened attraction to becoming a full-fledged Russian subject, as one might expect, but a decrease in naturalization rates among foreigners residing in Russia. The main reason was precisely that naturalization would not add considerably to the package of rights and privileges newly provided for entrepreneurial foreigners. However, the number of unnaturalized immigrants was rapidly growing, as was their contribution to the modernization of Russian economy.

5 The discussion of the border control policies during several decades prior to WWI brings the author closer to the nationalistic and restrictive aspects of the imperial management of citizenship. Skillfully applying the histoire croisée method, Lohr traces the shorter- and longer-term implications of the mass deportations of Russian-subject (mostly Polish and Jewish by ethnicity) wage workers from Germany in the 1880s. Being obviously part and parcel of the new Bismarck-inspired population engineering, it sped up the Russian crackdown on the landholding rights and other privileges of both German (in a large majority) and non-German unnaturalized colonists in the three Right-Bank Ukrainian provinces - a borderland, highly problematic because of the strong Polish presence and the rising rivalries with Germany and Austria-Hungary. Predictably, these new restrictions slowed economically incentivized immigration of 
foreign subjects to one of the empire's most agriculturally productive regions. In another example of transnational entanglement, this time at a far greater geographical distance, the clash over border control with Germany reverberated in the introduction of a new guest worker system for the Chinese and Koreans in the Russian Far East, similar to a system that Germany had earlier introduced for Russian-subject seasonal workers, seeking to resolve "the tension between ethnonational goals and the need for cheap labor through citizenship policy" (p. 80). Overall, while discouraging migrants looking for land, the Russian government was still interested in migrants looking "for industrial jobs or urban entrepreneurial opportunities" (p. 81).

6 The "hold" half of the complex "attract-and-hold" story, in my view, has less to do with the narrative of Russia's growing openness to the outside world. Major restrictions on legal emigration and denaturalization were formidable, and they persisted throughout the imperial era. Departure from the country to take up residence abroad, unless unbeknownst to the authorities, was permitted only on the condition of renouncing one's Russian subjecthood and signing a pledge never to return. This draconian measure, Lohr argues, was applied primarily to Muslims, Jews, and other religious and ethnic non-Russian minorities whose members' "departure was conceived as something akin to treason" (p.92). Concurring with Lohr that up to the late $19^{\text {th }}$ century mass emigration (be it bluntly enforced or powerfully stimulated by indirect factors) did not concern the ethnically Russian populations, a similar association of departure or absence from the country with treason should be emphasized as applying even in the case of those specific Russian nobles whose actions (such as conversion to Roman Catholicism) came to be deemed as showing disloyalty to the dynasty and, by implication, the country.

7 Likewise, the late imperial era's debates over denaturalization as described by Lohr reveal the tenacity of the bureaucracy's punitive logic despite an increasingly vocal reformism. As defined by the notorious article 325 of the Criminal Statute on Punishment, denaturalization most frequently served as retaliation for a subject's neglect of his duties to tsar and state. What then about the possibility of legal denaturalization? Although many participants in these debates agreed that obtaining it was an excessively cumbersome procedure requiring in each and every case the emperor's formal approval, little was eventually done to facilitate legislating the right of denaturalization without an accompanying ban on return into the empire.

8 Lohr perceptively demonstrates an international-domestic knot about this controversy, as Russia's claim to control its subjects' denaturalization was challenged by the United States policy based on the principle of the universal freedom to denaturalize. This conflict mostly affected Russian-born Jews who had been naturalized in the U.S. without Russian permission and afterwards, for business or family reasons, sought reentry to Russia. Such people continued to be liable to the restrictions imposed on Jews in Russia that would remain intact even after the 1905 revolution. Even the relative liberalization of Jewish emigration in the 1890s (partly a result of the consolidating categorization of all of Jewry as an unwanted "element") did not alleviate the eternal ban on return - the regime might desire a bulk of the Jewish population to be jettisoned, but this still was to be staged as a punishment for presumed disloyalty.

9 At the same time, by the early $20^{\text {th }}$ century, the imperial government began to show interest in keeping ties with emigrants from the perceived ethnically "core" parts of the population (such as certain groups of Old Believers), to which end maintaining 
control over denaturalization so as to keep it a hard option appeared necessary. Yet, for all Russia's peculiarities on this score, Lohr underlines that the growing preoccupations with population policy and the "zero-sum game" fears of losing subjects to another citizenship, enhanced particularly by the introduction of universal conscription and, generally, the sense of an imminent big war, were at this time common to other countries as well.

10 The policies of citizenship during World War I, Lohr argues, inaugurated the reversal of a number of internationalizing trends that had originated from the era of Great Reforms. In a sweep of increasingly discriminatory measures, initially targeting only enemy aliens (first of all subjects of Germany, Austria-Hungary, and the Ottoman Empire) and their property, the civilian and military authorities proceeded to degrade the legal status of naturalized immigrants, blocked denaturalization and naturalization of any kind, and made a step toward defining, in a reductionist fashion, political loyalty through ethnicity. This sealing of the citizenship boundary is only partially attributable to the influence of Russia's allies' similar experience; the Russian wartime ban on naturalization was unmatched by any major power at that time and anticipated the Bolshevik approach to citizenship.

11 Arising from this point, the central theme of the book's final chapter is the further, even more radical, shift toward isolationism during the first Soviet decade and a half. In a probing account, Lohr traces the long and not quite straightforward journey of early Soviet citizenship policy, based in principle on class rather than ethnicity, from the ideologically inspired promise of easy immigration and naturalization for foreign workers to the incremental tightening of control over movements across borders, culminating in an almost total prohibition of emigration, denaturalization, and immigration. In essence, only the latter half of the "attract and hold" symbiosis eventually survived.

12 As Lohr insists, this Soviet "unprecedented swing toward autarky in the late 1920s" was "a distinctly Soviet decision that amounted to a dramatic break from Russian traditions," being "much more the fruit of trends that began during World War I" (p. 10, 176). Of all the author's generalizations and strong opinions, this point perhaps most acutely invites discussion in future studies. In my view, to be more convincing, it would have to go beyond the scope of studying the mostly economically motivated "exit-entry" transitions and be developed in a broader context of Russian imperial politics of subjecthood-as-loyalty at the intersection of nationality, religion, and assimilation (i.e., naturalization in a broader sense). I believe that the deep-seated notions of allegiance, trustworthiness, and assimilability, as well as phobias regarding treason and apostasy, ${ }^{1}$ connected the management of subjecthood within the specific domain of immigration, emigration, and border control to the adjacent sphere of domestic nationality and confessional policies. Probably, such connection took place also across long periods of time. For instance, as is suggested by the evidence presented in this very book, especially concerning the conundrum of naturalization and denaturalization, there might well have been a certain continuity between the persistent imperial patterns of ethnic or ethnoreligious scapegoating and xenophobic categorization, on the one hand, and the Soviet - of course far more violent persecution of "enemy nations" and "diaspora minorities," on the other. ${ }^{2}$

Perhaps guided by the idea of a Soviet "dramatic break from Russian traditions," Lohr sometimes tends to somewhat modernize the pre-World War I politics of citizenship. 
His above-mentioned argument about the 1860s innovations as positively pushing towards "a unified citizenship" is questioned by the subsequent analysis of the significant limitations and exceptions that attested to the persistence of particularism and the "separate deals" paradigm in the realm of subjecthood (p. 55, 57-58). Rather than the author's stress on universalism in matters of naturalization, these exceptions call to mind what Benjamin Nathans, in his study of imperial Jewish politics of the same era, has called "selective integration," thus emphasizing the continuous importance of membership in a certain social category even for those Jews who would meet the newly established standards of economic "usefulness" and could be permitted to reside beyond the Pale of Settlement. ${ }^{3}$ Notably, membership in a certain social group remained the prerequisite for foreigners' naturalization as well.

14 Turning to technicalities, one should notice that the author's argument would have benefitted from better organization of archival sources' citation. Here and there, archival legends without an accompanying indication of the individual document's type, author(s), and date appear even in the notes to major points in the text.

15 All possible qualifications aside, Eric Lohr's study fills in a considerable gap in our knowledge about practices of being or seeking as well as ceasing to be a Russian subject and offers fresh perspectives on the interwoven issues of citizenship, loyalty, governance, and population policies in Russian history.

\section{NOTES}

1. Insofar as Lohr's argument is concerned with comparative context, this recent inquiry into the Ottoman politics of religious conversion as interrelated with the changing attitudes toward citizenship may be of interest to the book's readers : Selim Deringil, Conversion and Apostasy in the Late Ottoman Empire (New York : Cambridge University Press, 2012), 156-196.

2. Terry Martin, Affirmative Action Empire: Nations and Nationalism in the Soviet Union, 1923-1939 (Ithaca : Cornell University Press, 2001), 325-43.

3. Benjamin Nathans, Beyond the Pale: The Jewish Encounter with Late Imperial Russia (Berkeley : University of California Press, 2002), 69-79, 231-239.

\section{AUTHORS}

\section{MIKHAIL DOLBILOV}

University of Maryland, College Park 